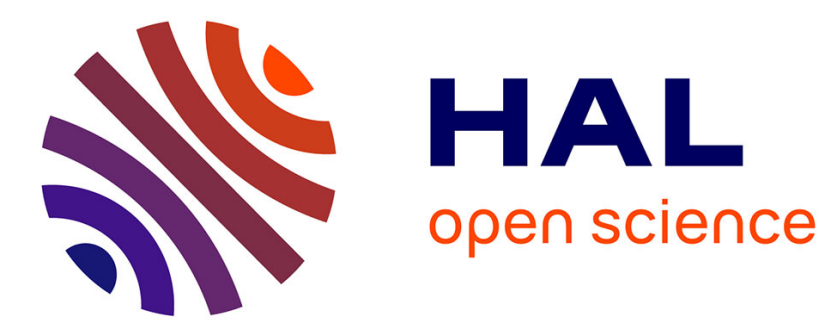

\title{
Ecological intensification for crop protection
}

Alain Ratnadass, Marc M. Barzman

\section{To cite this version:}

Alain Ratnadass, Marc M. Barzman. Ecological intensification for crop protection. Agroecology and Global Change, , 2014, 10.1007/978-3-319-06016-3_3 . hal-02797996

\section{HAL Id: hal-02797996 https://hal.inrae.fr/hal-02797996}

Submitted on 5 Jun 2020

HAL is a multi-disciplinary open access archive for the deposit and dissemination of scientific research documents, whether they are published or not. The documents may come from teaching and research institutions in France or abroad, or from public or private research centers.
L'archive ouverte pluridisciplinaire HAL, est destinée au dépôt et à la diffusion de documents scientifiques de niveau recherche, publiés ou non, émanant des établissements d'enseignement et de recherche français ou étrangers, des laboratoires publics ou privés. 


\title{
Ecological Intensification for Crop Protection
}

\author{
Alain Ratnadass and Marco Barzman
}

\begin{abstract}
We need to break away from intensive agriculture based on non-renewable and toxic inputs. Safer practices are indeed emerging. Sustainable agriculture started about 50 years ago with the design of integrated pest management (IPM) to counteract pesticide misuse and abuse. Ecological intensification emerged only a few years ago. Here we review the literature to compare ecological intensification and IPM, from the point of view of crop protection. We present also agroecology and organic farming. Neither ecological intensification nor IPM have philosophical bases such as agroecology, or to an even larger extent, biodynamic agriculture. Ecological intensification, IPM and agroecology are polysemous, flexible and pragmatic approaches, whereas organic farming is well-defined by its scope and standards. Ecological intensification, in explicitly pursuing the goal of increasing food production to feed the planet, differs from agroecology, whose proponents think that the view that world hunger will be solved by merely increasing yield is an oversimplification. In terms of cropping system design, in its actual practice, IPM often remains based on methods that increase the efficiency of chemical pesticide use. Or, along with organic agriculture, it may remain based on substitution of pesticides by less harmful alternatives. In contrast, ecologically intensive crop protection usually requires cropping system redesign.

In terms of ecosystem service provision, IPM tends to focus on the pest-pathogen regulation service. In contrast, both ecological intensification and agroecology pay attention to both practices which were designed for crop protection and biomass provision purposes, as well as practices with broader scope, primarily designed to offer other ecosystem services which are found to have indirect effects on crop
\end{abstract}

\footnotetext{
A. Ratnadass $(\bowtie)$

UR HortSys, CIRAD, Boulevard de la Lironde, F-34398 Montpellier, France

e-mail: alain.ratnadass@cirad.fr

M. Barzman

Eco-Innov, INRA, F-78850 Thiverval-Grignon, France

e-mail: Marco.Barzman@grignon.inra.fr
} 
protection. This chapter also describes selected tropical case studies of crop protection, such as upland rice seed-dressing and fruit fly control in orchards, to compare and contrast crop protection in these contexts. Finally, we propose to consider IPM and ecologically intensive crop protection as complementary rather than conflicting approaches. The concept of "ultimate IPM" brings IPM closer to ecologically intensive crop protection. This new approach involves starting from a nearly natural ecosystem to which inputs are gradually added when absolutely necessary, rather than starting from a conventional agroecosystem and gradually remove inputs from it.

Keywords Agroecology - Ecologically intensive agriculture - Integrated Pest Management $\bullet$ Ecological engineering $\bullet$ Organic farming $\bullet$ Conservation agriculture - Push Pull • Crop protection - Sustainable agriculture - E-S-R framework • Ecosystem services

\section{Abbreviations}

DDT dichlorodiphenyltrichloroethane

DMC Direct-seeding, mulch-based cropping (systems)

E-S-R Efficiency-Substitution-Redesign

GM Genetically modified (crop/plant)

IPM Integrated pest management

US United States (of America)

\section{Introduction}

A number of concepts have emerged during the last century as pathways toward sustainable agriculture. They are based on the perceived need to break away from the dominant paradigm that gave rise to an intensive type of agriculture associated with artificial conditions, biodiversity reduction and reliance on non-renewable and toxic inputs. Integrated Pest Management (IPM) emerged more than half-a-century ago from early reactions to widespread misuse and abuse of toxic inputs in agriculture (Carson 1962; Stern et al. 1959). The scope of IPM is crop protection and its driver is pesticide use reduction. More recent approaches that are broader in scope have emerged. Ecological intensification emerged a few years ago (Bonny 2011; Doré et al. 2011; Griffon 2013). It is closely related to the concept of agroecology (Altieri 1995) particularly with ecological engineering for pest management as its application to crop protection (Nicholls and Altieri 2004).

This paper describes how ecological intensification, agroecology and IPM emerged. It compares the three approaches to each other and to other possible pathways to sustainable agriculture (Pretty 2008) such as organic farming and 
eco-agriculture relative to their crop protection dimension. It then discusses how they differ and how they may be synergistic rather than conflicting according to:

(i) the way they fit within the Efficiency-Substitution-Redesign (E-S-R) framework (Hill and MacRae 1995), particularly with regards to their acceptance or exclusion of chemical pesticides and genetically modified (GM) crops;

(ii) the way they contribute to ecosystem services beyond crop protection, particularly in the context of global environmental changes.

\section{The Emergence of Alternatives to Agrochemistry-Based Crop Protection}

\section{Biodynamic Agriculture}

Historically, the anthroposophic movement of the Austrian thinker Rudolf Steiner in the 1920s in central Europe, and its associated biodynamic agriculture movement was the first self-claimed alternative to the industrialization of agriculture (Steiner 1924). In its rejection of science in agriculture, it excluded even "natural" (biological or mineral) crop protection substances such as copper, sulphur, or arsenic at a time when there were no synthetic pesticides per se. Nevertheless, some specific "preparations" or recipes were proposed to combat crop diseases such as boiled horsetail plant (Equisetum arvense) to prevent fungal diseases. Certain principles which may appear esoteric to some were also proposed to combat insect and rodent pests. These include incineration of insect pests or rodent skins, with ashes diluted at homeopathic doses and applied according to cosmic factors such as the movements of the moon and planets.

\section{Organic Farming}

Organic farming was independently developed in the 1940s in England through the work of sir Albert Howard (1943) who was inspired by his experience with traditional farming methods in India, which notably served as the basis to "the principles which appeared to underlie the diseases of plants:

1. Insects and fungi are not the real cause of plant diseases but only attack unsuitable varieties or crops imperfectly grown. Their true role is that of censors for pointing out the crops that are improperly nourished and so keeping our agriculture up to the mark. In other words, the pests must be looked upon as Nature's professors of agriculture: as an integral portion of any rational system of farming.

2. The policy of protecting crops from pests by means of sprays, powders, and so forth is unscientific and unsound as, even when successful, such procedure merely preserves the unfit and obscures the real problem - how to grow healthy crops. 
3. The burning of diseased plants seems to be the unnecessary destruction of organic matter as no such provision as this exists in Nature, in which insects and fungi after all live and work".

Organic farming practices have been standardized and codified by the International Federation of Organic Agriculture Movements (IFOAM). Regarding the use of plant protection products, biological and mineral crop protection substances are allowed in organic farming, although - ideally - priority is given to preventive methods (Letourneau and van Bruggen 2006; Zehnder et al. 2007).

\section{Integrated Pest Management}

IPM as a concept appeared as a reaction to the widespread and systematic use of synthetic pesticides, particularly DDT, after World War II, and was elaborated as early as 1959 (Stern et al. 1959), prior to the publication of the renowned book "Silent Spring" by Rachel Carson (1962). The emergence of pesticide resistance further boosted its development. IPM gained worldwide recognition following the quick resolution of a food security crisis in Indonesia in the mid-1970s created by the insecticide-resistant rice brown plant-hopper and the suppression of its natural enemies. The IPM programme in question, which included from the late 1970s to the mid-1980s the phase-out of many broad spectrum insecticides and a rapid $65 \%$ reduction in overall pesticide use was associated with an immediate $12 \%$ increase in rice yields (Röling and van de Fliert 1994). Historically, IPM emerged in the area of insect management with the idea that an integration of practices could reduce the likelihood of requiring insecticides that may be used "only as a last resort". The use of the concept of treatment threshold was a major tool by which the frequency of pesticide treatments against arthropod pests could be reduced. It was assumed that the approach could be generalised to pathogen and weed management.

The passing in 2009 of two important pieces of European legislation (Regulation $1107 / 2009^{1}$ and Directive 2009/128/EC ${ }^{2}$ ) marks a turning point and places IPM again in the limelight. The decrease in the availability and portfolio composition of plant protection products in the European Union already during the last decade and the new legislative landscape mean that in future farmers will no longer have access to the entire range of pesticides they use today and that they will have to adopt IPM, incorporating alternative approaches or techniques to reduce their dependency on pesticide use. By December 2012, most EU Member States completed and initiated the implementation of the National Action Plans which will pave the way to reach the new objectives and by January 2014, Member States are expected to show how the principles of IPM are implemented.

\footnotetext{
${ }^{1}$ http://eur-lex.europa.eu/LexUriServ/LexUriServ.do?uri=OJ:L:2009:309:0001:0050:EN:PDF ${ }^{2}$ http://eur-lex.europa.eu/LexUriServ/LexUriServ.do?uri=OJ:L:2009:309:0071:0086:en:PDF
} 
The concept of "integrated production" (IP) was also proposed by the International Organization for Biological and Integrated Control of Noxious Animals and Plants (IOBC) as a desirable approach to the development of more sustainable crop protection. This approach takes into account not only crop protection measures, but all farming practices at the entire agroecosystem level which affect pest management (Boller et al. 2004). The approach is embodied in a series of IP guidelines that have been used in association with subsidies in Switzerland and in Emilia-Romagna Region (Italy) (BLW 2013; Stäubli 1983). In some other European countries, it was applied to vegetable and fruit production, e.g., in France where, although promising, integrated fruit production remained limited due to lack of public support (Bellon et al. 2006). Recently, with the implementation of the European Framework Directive 2009/128/EC on the Sustainable Use of Pesticides, several governments have placed emphasis on the IP guidelines in their pesticide National Action Plans. ${ }^{3}$

\section{Agroecology}

German zoologists in the 1930s-1960s, were among the early promoters of the term and concept of agroecology, along with European and American agronomists and crop physiologists, and emphasised the application of agroecology to pest management (Friedrichs 1930 in Wezel et al. 2009, Tischler 1950 in Wezel et al. 2009). In the 1970s-2000s, agroecology further developed as a science, a movement and a set of practices primarily as a reaction of American ecologists (e.g., Miguel Altieri, John Vandermeer) to the excesses of the Green Revolution and its negative impact on small-holders in developing countries (Altieri 1995; Vandermeer 1995; Wezel et al. 2009). Proponents of agroecology historically maintain a suspicion regarding the common wisdom goal of "feeding the planet" in the face of a "population explosion". They claim that the view that world hunger will be solved by merely increasing yields - rather than by increasing total productivity with respect to land and inputs and by addressing social inequality - is an oversimplification serving the needs of developed countries (Moore Lappé et al. 1998; Altieri and Nicholls 2012).

In his definition of agroecology, Miguel Altieri particularly stressed the "pest \& disease regulation" pillar (Altieri 1995). Deguine et al. (2008) further developed the application to crop protection within the concept of agroecology, which can be referred to as agroecological crop protection. For instance, Shennan et al. (2005, in

\footnotetext{
${ }^{3}$ SCAR Collaborative Working Group on integrated pest management for the reduction of pesticide risks and use ANALYSIS OF RESEARCH AND EXTENSION NEEDS FOR THE DEVELOPMENT OF IPM Final report of a survey conducted among European countries. Last revision April 17, 2013 http://www.endure-network.eu/content/download/6765/48872/file/ Final\%20report\%20SCAR\%20IPM\%20CWG.pdf
} 
Deguine et al. 2008), wrote: "An agroecological approach to agriculture involves the application of ecological knowledge to the design and management of production systems so that ecological processes are optimized to reduce or eliminate the need for external inputs. Nowhere is this more apparent than in the management of agricultural pests." Within the agroecology mindset, it is the use of cultural techniques to effect habitat manipulation and enhance biological control that is more specifically referred to as ecological engineering for pest management (Gurr et al. 2004). Among the "affiliated" sets of practices, conservation agriculture and agroforestry place less emphasis on pest regulation - except for weed suppression in the former.

\section{Ecological Intensification}

To some extent, crop protection issues are also central in the "ecological intensification" approach, where natural ecosystems serve as a source of inspiration (Doré et al. 2011; Malézieux 2012). That is why ecologically intensive crop protection emphasises the use of biological processes to regulate pest populations as an alternative to direct control via synthetic pesticides.

In any case, the ecologically intensive approach to crop protection differs from organic farming in its flexibility regarding the use of chemicals, and from agroecology in its explicit goal of increasing the quantity of food produced to "feed the planet" via a certain form of intensification (Griffon 2006). Its explicit and primary goal of increasing agricultural production is a notable difference with agroecology which puts forward a range of environmental, economic, social and cultural goals. Proponents of ecological intensification, referring to lower yields attained in organic cereal production, do not perceive organic farming as pursuing this goal.

Thus, among the major claimed pathways to sustainable agriculture, organic farming, agroecology and ecological intensification have well-developed crop protection dimensions. Biodynamic agriculture poorly covers this aspect of crop production while IPM is obviously exclusively dedicated to pest management.

\section{Relationship Between IPM and Ecological Intensification for Crop Protection}

\section{Definitions and Principles of IPM}

IPM has a number of definitions. One, adopted by the European Network ENDURE, which has taken upon itself to provide research and development support to the implementation of IPM (ENDURE 2011) as well as by a number of national and international organisations and agencies, is the following:

IPM is a sustainable approach to managing pests by combining biological, cultural and chemical tools in a way that minimises economic, environmental and health risks. 
With the mandatory implementation of IPM to be achieved by 2014 in all European Union Member States as called for by Directive 2009/128/EC, ${ }^{4}$ which regulates the use phase of pesticides and establishes a new framework to "achieve a sustainable use of pesticides by promoting the use of integrated pest management and of alternative approaches or techniques such as non-chemical alternatives", much attention is paid to how this legislation defines IPM. It states that: "IPM means careful consideration of all available plant protection methods and subsequent integration of appropriate measures that discourage the development of populations of harmful organisms and keep the use of plant protection products and other forms of intervention to levels that are economically and ecologically justified and reduce or minimize risks to human health and the environment. 'Integrated pest management' emphasizes the growth of a healthy crop with the least possible disruption to agroecosystems and encourages natural pest control mechanisms".

According to the above-mentioned EU directive, IPM practitioners must satisfy eight principles:

- Principle 1 - Achieving prevention and/or suppression of harmful organisms

- Principle 2 - Monitoring

- Principle 3 - Decision based on monitoring and thresholds

- Principle 4 - Non-chemical methods

- Principle 5 - Pesticide selection

- Principle 6 - Reduced use

- Principle 7 - Anti-resistance strategies

- Principle 8 - Evaluation

The first principle emphasises preventive/prophylactic indirect measures, followed by pest monitoring and decision-making on curative measures based on thresholds, first with non-chemical methods, then with the least harmful pesticides if deemed necessary. ENDURE promotes the view that IPM is a continuously improving process in which innovative solutions are integrated and locally adapted as they emerge and contribute to reducing reliance on pesticides in agricultural systems. One could thus define an IPM continuum (Ohmart 2008, 2009) as follows:

- An early-stage IPM based for instance on selecting IPM-adapted pesticides or more generally on optimising pesticide use to reduce use and risks.

- More advanced stages ranging from the use of threshold-based pesticide application to combination of tactics and prevention strategies, or more generally aiming to reduce reliance on pesticides.

- "Ultimate IPM" where no direct control methods are needed once cropping systems with in-built robustness vis-à-vis pests, weeds and diseases is established.

For the purposes of our comparison, the main message regarding IPM from the point of view of what it has achieved in the field, is that it is helpful in reducing pesticide use and impact but that at least in its de-facto implementation, it has tended to remain within the realm of chemically-dependent crop protection.

\footnotetext{
${ }^{4}$ http://eur-lex.europa.eu/LexUriServ/LexUriServ.do?uri=OJ:L:2009:309:0071:0086:en:PDF
} 


\section{Definition and Principles of Ecological Intensification for Crop Protection}

While the goal of IPM centers on crop protection, ecological intensification covers all aspects of production. It can nevertheless be compared to IPM with regards to its application to crop protection. Michel Griffon, one of the founders of ecological intensification, defined it as "an approach based on the enhancement of agroecosystem functionalities, of agroecosystem component complexity and diversity to improve agroecosystem resilience, and on the harnessing of 'biologically-inspired' innovations". The latter concept refers to techniques that mimic natural functions (Griffon 2013). He also characterised ecological intensification as a genuine ecological engineering approach: "a management and design of sustainable, adaptive, multifunctional environments, inspired by or based on mechanisms that govern ecological systems". "Ecological engineering" was first proposed as an approach in its own right, defined as "the design of sustainable ecosystems that integrate human society with its natural environment for the benefit of both" (Mitsch and Jorgensen 2003), not necessarily encompassing agroecosystems per se. In its application to agroecosystems, it is, however, the use of cultural techniques to effect habitat manipulation and enhance biological control that most readily fits the philosophy of ecological engineering, as a part of the agroecology mindset (Gurr et al. 2004). It could therefore more appropriately be termed "agroecological engineering".

In its crop protection dimension, ecological intensification proposes to develop pest management strategies based on cultural practices informed by ecological knowledge and believe this can result in significantly increased crop production due to decreased crop loss, added to other beneficial effects on crop physiology, rather than on high-technology approaches that include synthetic pesticides and genetically engineered crops. Some nevertheless believe the latter to be compatible with ecological engineering, and in any case necessary if the objective of food security is to be met (Birch et al. 2011).

Positioning organic farming and IPM relative to ecological intensification, i.e., in reference to their reliance on ecological processes, is not easy. While the definition of organic farming is very clear, IFOAM standards have allowed the emergence of two distinctive approaches. One, which we term "low-input organic farming", is based on prevention and indirect methods of controls and is close to agroecology. The other, which we term "large-scale organic farming", is based on substitution of synthetic inputs with external organic inputs and does not in the end differ much from industrial conventional farming (Darnhofer et al. 2010; Guthman 2000; Rosset and Altieri 1997).

IPM - within a continuum ranging from early-stage to ultimate IPM - , agroecology and ecological intensification take on a number of meanings as well. For instance, Griffon (2013) considers ecological intensification to encompass the entire range from low to high "environmental value" practices, with conventional agriculture considered as having low, conservation agriculture as having low to medium, and organic farming as having high environmental value. 
For our comparison of approaches, it is the "intensification" aspect of ecological intensification that is most pertinent as it conveys active and interventionist research and extension attitudes regarding the manipulation of ecological processes. This contrasts with the more descriptive attitudes historically prevalent in the science of ecology (Jackson and Piper 1989) and possibly with agroecology which, at least in its earlier phases, devoted much effort in documenting and understanding the ecological rationale underlying traditional tropical agriculture.

However, the "engineering" aspect of ecological engineering applied to agroecosystems, as a part of agroecology (see above) also conveys such active attitude, but with a view of sustaining rather than increasing agricultural production. In addition, the idea of sort of "controlling" the nature, via the engineering of ecological processes, which is part of the ecological intensification mindset, is much less so in the agroecological mindset, even if it comes to ecological engineering. Also, the idea of a compulsory need for changing human nature, calling rather for sufficiency in a world of scarcity (Rahbi 2008; Mathijs 2012), is part of the agroecological movement (although more in its philosophical than scientific mindset), whereas it is not in essence part of the ecological intensification thinking. Actually, neither ecological intensification nor IPM have philosophical bases such as agroecology, or to an even larger extent, biodynamic agriculture.

The "ecological" dimension of ecological intensification, agroecology and lowinput organic farming is in any case more developed than in IPM, which, although scientifically based, mainly mobilizes knowledge on the phenology of the crop and the bio-ecology of pests in view of combining control tactics and establishing economic injury levels and treatment thresholds. So, at least in its practice, IPM implementation remains dependent on pesticides, and the ecological concepts and processes are less essential than in the ecological intensification approach. One can note in this regard that in the practice of IPM, the notion on "ecology" mainly refers to reducing adverse ecological impacts rather than making full use of ecological processes, which are central in ecologically intensive crop protection.

\section{Conflicts, Synergies or Necessary Trade-Offs Between IPM \& Ecologically Intensive Crop Protection}

\section{IPM Versus Ecological Intensification in the E-S-R Framework}

In the E-S-R (Efficiency-Substitution-Redesign) framework provided by Hill and MacRae (1995), IPM may in its early-stage remain based on methods aiming at increasing the efficiency of pesticides $(\mathrm{E})$, or on the substitution of these pesticides by less harmful alternatives (S). Complete redesign of agroecosystems (R), in view of achieving "deep sustainability" or attaining "ultimate IPM", is not mandatory. In contrast, ecological intensification and ecological engineering applied to crop protection make use of biotic and abiotic processes rather than substituting one sort of input by another. 
Reliance on ecological processes usually requires redesign of cropping systems achieved via plant spatial and temporal diversification, and the creation of an environment that is favourable to natural enemies. Although one could think that redesign is necessarily based on the integration of multiple management tactics with partial effects, this is not mandatory, since a single agroecosystem redesign measure via plant species diversification may result in pest/pathogen regulation via several parallel pathways (Ratnadass et al. 2012a). The regulation pathways may be "bottom-up", from lower to higher trophic levels, i.e., from autotrophic plants to herbivore pests or plant pathogens (e.g. allelopathic effects, or stimulo-diversionary effects). Or they may be "top-down", i.e., from higher to lower trophic levels, i.e., from predators to pests (namely the various forms of biological control). In contrast, with the present understanding of the rapid capacity of pests to evolve and adapt to single tactical control measures, the IPM approach is necessarily based on the combination of several management methods with partial effects, with a view to preventing or delaying their being circumvented by the target pests.

So one major difference between the actual practice of IPM and ecologically intensive crop protection is that the former may remain based on methods aiming at increasing the efficiency of chemical pesticides, or on their substitution by less harmful alternatives, while the latter usually requires complete cropping system redesign. A second major difference is that while IPM necessarily involves the integration of several management methods with partial effects, to simultaneously address multiple pests or delay overcoming by pests, pathogens and weeds, while ecologically intensive crop protection may rest on a single redesign measure, resulting in their regulation via a number of pathways.

\section{Regarding Chemical Pesticides}

So unlike organic farming, both IPM and ecologically intensive crop protection allow pesticides, even though they admit that those should be "ideally" avoided. The IPM approach summarized by Vandermeer (1995) emphasises IPM principle 1 (prevention): "don't spray poisons unless it is necessary and manage the ecosystem in such a way that it doesn't become necessary". Thus, agroecological or ecologically intensive crop protection can be seen as key to the first principle of IPM and to the ultimate stage of IPM, when redesign has been so successful that no other measure is necessary.

The perspective of IPM is reduction of pesticide use, but not that of other agrochemicals. It is also based on the integration of several techniques and externally produced inputs, such as semio-chemicals, precision agriculture, biological control agents for inundative release. These are not generally part of the toolbox of agroecology or ecological intensification, or that of low-input organic agriculture, particularly regarding synthetic pesticides and chemical fertilizers.

The emphasis of "agroecology-based approaches" such as ecological engineering applied to agroecosystems and ecologically intensive agriculture, is on the enhancement of biological processes as replacement of chemical inputs. Such inputs 
are excluded from organic farming, while they are allowed, at minimal doses, in agroecology-based approaches, possibly as "starters" to mobilize biological processes for farmers' benefit with a view to their eventual suppression ultimately. In contrast, non-use of chemical inputs is a key pre-requisite in organic farming.

In the actual practice of IPM - as opposed to IPM theory which purports that pesticide use is only as a last resort - some observers think that relying on thresholds could even unintentionally encourage the use of pesticides. Indeed, the use of thresholds requires intensive monitoring of pests which in some cases may give pests excessive attention which, coupled with risk aversion, would frequently translate to a decision to spray. Other proponents of IPM emphasise the importance of ensuring the availability of a wide range of pesticides. Such availability is seen to help reduce the emergence of pesticide resistance and to function as a "safety net" making it possible to experiment with innovative approaches with the guarantee that pesticides could be used as a last resort if something goes wrong. "Minor use" proponents, recognising the diversification of arable cropping systems as a major strategy to generate more robust cropping systems, also emphasise the need for pesticides registered for use on new crops to be inserted in a crop sequence. Otherwise, in the absence of operational control methods, they argue, farmers will not experiment with the new crops.

Ecological intensification and IPM - unlike organic farming - are polysemous or encompass a broad continuum. They are therefore not easily defined by their scope or precise codification in view of certification. Standards of organic farming are relatively well harmonized worldwide at all levels, and farmers identify themselves with organic farming, which has gained high credibility. The flexibility of both IPM and ecological intensification as compared to organic farming explains why they are difficult to label.

Although organic farming and both agroecology and ecological intensification have many crop protection aspects in common (Letourneau and van Bruggen 2006; Zehnder et al. 2007), there are differences. The exclusion of chemical pesticide treatments in organic farming is a consequence of its market orientation and dependence on certification. That is why in cases of a massive pest attack, an organic farmer would rather lose the crop than the certification, something which agroecological subsistence farmers cannot afford.

Organic agriculture may be environmentally and economically sustainable at more local scales, but ecological intensification proponents question its social sustainability at the global scale, in terms of its ability to feed the planet. The debate over the capacity of organic agriculture in terms of production is still open. In any case social sustainability via the "food production" service is considered primordial in ecological intensification.

The attitude of IPM and ecologically intensive agriculture toward the use of agrochemicals is therefore more pragmatic than that of organic farming. However, within an ideal classical IPM framework, synthetic pesticides cannot be applied as a systematic preventive measure, but only as a last resort curative option decided via the use of thresholds. Conversely, the preventive use of pesticides, even synthetic, is not excluded from the ecologically intensive approach, if it can boost some 
ecological processes. It should however be kept to a minimum, avoiding adverse impacts on other ecological processes pertinent to agricultural production, on human health or on other environmental dimensions.

For instance, ecological intensification might favour the application of herbicide on a natural cover, as in conservation agriculture systems, to allow direct seeding into the mulch thus avoiding ploughing to reap the full benefit of undisturbed soil biological activity (Séguy et al. 2012). Similarly, seed-dressing with a targeted systemic insecticide could be included in an ecological intensification programme if it is deemed mandatory to avoid total crop failure in some specific environments: see $\S$ "Relevance of seed-dressing with targeted systemic insecticides under the "ecological intensification for crop protection" approach" in this chapter.

The targeted use of insecticide may also help extend the range of application of another typically agroecological or "ecologically intensive" technique such as pushpull technology (Cook et al. 2007; Khan et al. 2010). When "dead-end" trap plants are not available, using chemical pesticides in alternation with biological insecticides may be desirable. Chemical pesticides in alternation with Bt toxins from the soil bacterium Bacillus thuringiensis or with Spinosad from the soil bacterium Saccharopolyspora spinosa -both allowed in organic agriculture- in an "assisted push-pull" or "attract \& kill" approach may delay the build-up of resistance to the latter. In this case also, the adverse impact of pesticides is kept at a minimum, since those mainly biological products are not sprayed on the crop but on the trap plants, either directly or in mixture with liquid baits, at very low rates, namely $0.02 \%$ in the case of Spinosad in GF-120.

So for this chapter, one may actually consider that in both ecological intensification and IPM, priority is given to the absence of synthetic pesticide residues in the crop, food, and environment, rather than totally excluding use of pesticides or other chemical substances in the production process - a characteristic of organic farming. There may however be some differences in the way IPM and ecological intensification relate to pesticide use. IPM principles 1 (on prevention) and 3 (on basing decisions on observation) do not warrant the systematic preventive use of synthetic pesticides. In ecological intensification, such pesticide use is not excluded as long as its potential negative impacts are compensated by the boosting of positive ecological feedback loops.

\section{Regarding Botanical Pesticides and Biological Control}

Under IPM principle 4 (preference given to non-chemical methods), and principle 5 (selection of the least disruptive chemical), the use of botanical pesticides is encouraged. However, although more renewable than synthetic chemical pesticides, plantderived pesticides are not necessarily in line with the agroecological and ecological intensification approaches, since they rely on "substitution" rather than cropping system redesign (Ratnadass 2013). In addition, some plant-derived pesticides are not necessarily benign for the environment, e.g., rotenone, a broad-spectrum insecticide harmful to natural enemies and pollinators. This reservation however also 
applies to toxins of bacteria, e.g. Bt-toxins and Spinosad, if they are used in substitution to chemical insecticide sprays.

Nevertheless, the use of plant-derived pesticides may be a component of ecological engineering if sources of natural pesticides are part of the agricultural system. This is the case with Jatropha live-hedges planted around market-gardens to keep domestic animals away, or neem wind-breaks planted around orchards, with both also contributing to conservation biological control (Ratnadass and Wink 2012).

Regarding natural enemies, most IPM (ultimate IPM aside), relies more on augmentative biological control than on conservation biological control. Augmentation, which is the repeated release of purchased arthropod natural enemies or entomopathogenic fungi or nematodes may be considered as a mere substitute to chemical treatments, and would therefore not fit very well within the ecological intensification mindset. On the other hand, conservation biological control via natural enemy habitat management is very much in line with ecological intensification for crop protection and usually requires agroecosystem redesign.

So substitution of chemical pesticides by plant-derived pesticides, while it is welcome under IPM Principles 4 and 5, does not fit in the mindset of ecological intensification, unless plants producing pesticidal extracts are included in the redesign of the cropping system. Similarly, while augmentative biological control satisfies IPM Principles 1, 3 and 4, it is less in line with ecological intensification which gives preference to conservation biological control achieved via natural enemy habitat management, and usually requires redesign of the agroecosystem.

\section{Regarding Genetically Modified (GM) Crops}

While there is no question regarding the important role host plant genetic resistance plays as a preventive measure in IPM programs, the acceptance of GM crops is less clear-cut. The use of GM crops is considered by some as a tool for IPM just like that of any other pest-resistant cultivar (Birch et al. 2011; IPM CRSP 2011; Kennedy 2008). However, the use of Bt-transgenic crops, particularly cotton and maize, within the IPM framework, has been surrounded by unprecedented ethical debate and concerns about its safety for human health and the environment, including nontarget effects, gene flow, resistance build-up, emergence of secondary pests, as well as regulatory issues about the corporate control of agriculture, particularly in developing countries (Kennedy 2008).

As Bt-transgenic crops are "insecticidal plants", unlike conventionally bred insect resistant cultivars, their use is conflicting with IPM principle 3 (on pesticide application based on threshold), since, like for seed-dressing, "treatment" (=pesticide application) is systematic. In this respect, it is also conflicting with IPM principle 7 (on anti-resistance strategies), although resistance management refugia may delay Bt resistance buildup (Meissle et al. 2011). Furthermore, gene flow can contaminate non-GM crops, especially in neighbouring organic farms. They can also induce resistance, e.g., stem borers resistant to Bt, which, as sprays, is one of the only biopesticide options for organic farmers. Also, gene flow from herbicide-tolerant 
oilseed rape can make some weeds herbicide tolerant, which may pose a problem both in GM and conventional non-GM, and ecologically intensively managed fields.

On the other hand, while the use of "Round-UP® ready" herbicide-tolerant crops is considered by some a major tool of some forms of conservation agriculture, which is itself part of the agroecology and ecological intensification sets of practices, one can also stress that it is not part of IPM since it is predicated on the use of glyphosate, a synthetic herbicide.

Many proponents of IPM who emphasise the "I" of IPM, for example researchers from the ENDURE network who devote their efforts to combining multiple tactics to obtain a robust strategy, warn GM developers against the "silver bullet" attitude that a GM solution alone would sustainably solve a pest problem.

At present, regarding agroecological or ecological engineering approaches as well, even though it may mimic naturally occurring ecological processes, the use of genetically engineered plants is also still under debate. These plants may have negative effects on plant biodiversity in ecosystems via pathways such as gene flow (Altieri et al. 2004). Conversely, the use of herbicide-tolerant GM crops benefits soil biota biodiversity via enhanced no-till cultivation, and the use of Bt-transgenic crops benefits arthropod biodiversity via reduced insecticide use (Ammann 2005). On the other hand, GM crop proponents argue that within the ecological intensification framework, genetic engineering would be helpful in making GM "dead-end" trap plants available, such as Bt-collard or Bt-Indian mustard to protect cabbage from diamond-back moth damage (Shelton et al. 2008). Also, the use of a GM herbicide-tolerant crop would make easier combination with flower-strips as beetle banks and the management of the latter as potential weeds.

So while some consider GM crops as preventive tools for IPM just like any other pest-resistant cultivars, others stress that the prophylactic/systematic use of "insecticidal plants" is conflicting with IPM principles. The use of GM crops is also under debate within the ecological intensification approach, depending on whether one stresses its negative effects on plant biodiversity in ecosystems via other pathways, or the benefits for microbial and non-target arthropod biodiversity of the use of respectively herbicide-tolerant GM crops, via enhanced no-till cultivation, and insect resistant GM crops, via reduced insecticide use.

\section{Provision of Ecosystem Services in IPM and Ecological Intensification}

Crop pests and pathogens induce "negative" ecosystem services (or "disservices") to agricultural production, while beneficial biodiversity namely natural enemies of the former, provide "positive" ecosystem services (Zhang et al. 2007). Natural pest control is a major ecosystem regulating service contributing to the major provisioning service of biomass (food, forage, fibre or fuel) production to humans by agriculture (Millennium Ecosystem Assessment 2005; Power 2010). In this regards, farmers are the direct recipients of this service of reduction of crop loss (Avelino et al. 2011). 
The question raised now is to what extent IPM on the one hand, and ecological intensification on the other, may contribute to ecosystem services beyond this pest and pathogen regulation service - the reduction of biomass loss. Biodiversity conservation per se is for instance considered a major supporting service, and a source of controversy between different approaches. The first controversy pertains to the rationale of biodiversity conservation, namely for its mere intrinsic value or for its anthropocentric value (Maguire and Justus 2008; Nash 1967; Reyers et al. 2012). With such a mindset, having field borders or corridors "used" for ecological services such as crop protection is not "true" biodiversity conservation. Other controversies are embodied in the debates on land-sparing versus land-sharing (Ben Phalan et al. 2011), and eco-agriculture versus agroecology (Altieri 2004; McNeely and Scherr 2003), and their respective contribution to the biodiversity conservation.

Those latter controversies stem from conflicting results on the relationship between management intensity and species richness, and thus opportunity for biodiversity conservation in agroecosystems (Perfecto et al. 2005; Perfecto and Vandermeer 2008). Actually, this also refers to the increasing consideration of landscape ecology for crop protection goals within the ecological intensification framework. In this respect, this trend is shared with the IPM approach, and the increased consideration of area-wide IPM, which is somehow a way of re-designing cropping systems at the landscape scale (Chandler and Faust 1998).

Ecological intensification for crop protection pays attention to agroecological practices such as "push-pull" (Cook et al. 2007; Khan et al. 2010) or rice-duck farming (Ahmed et al. 2004; Furuno 2001; Su et al. 2012), which were primarily designed for crop protection and food and feed provision purposes. On the other hand, agroecology and ecological intensification also encompass sets of practices with broader scope, which were found to have indirect effects on crop protection, e.g. conservation agriculture (Ratnadass et al. 2006) (Fig. 1) and agroforestry (Avelino et al. 2011) (Fig. 2). The latter two practices were actually designed to offer other ecosystem services such as soil conservation/erosion prevention and hydrologic services, or greenhouse gas emission mitigation via carbon sequestration, which is particularly important in the context of climate change. While they obviously also make both producers and consumers benefit from indirect services such as improved health associated with reduced reliance on agrochemicals (Avelino et al. 2011), they are less attractive to consumers for their image of impact on human health, than organic farming is to its "customers". Without a market, payments for environmental services are thus needed to promote the development of such systems less dependent on pesticides, while maintaining or even improving yield and quality (Avelino et al. 2011). Provision of such other ecosystem services is also gaining importance in the context of global environmental changes and their impact on societal demands.

So regarding ecosystem services, ecological intensification addresses both practices which were designed for crop protection and food and feed provision purposes as well as practices with broader scope, which are found to generate indirect effects on crop protection. IPM is more seen as focussed on the mere pest/pathogen 


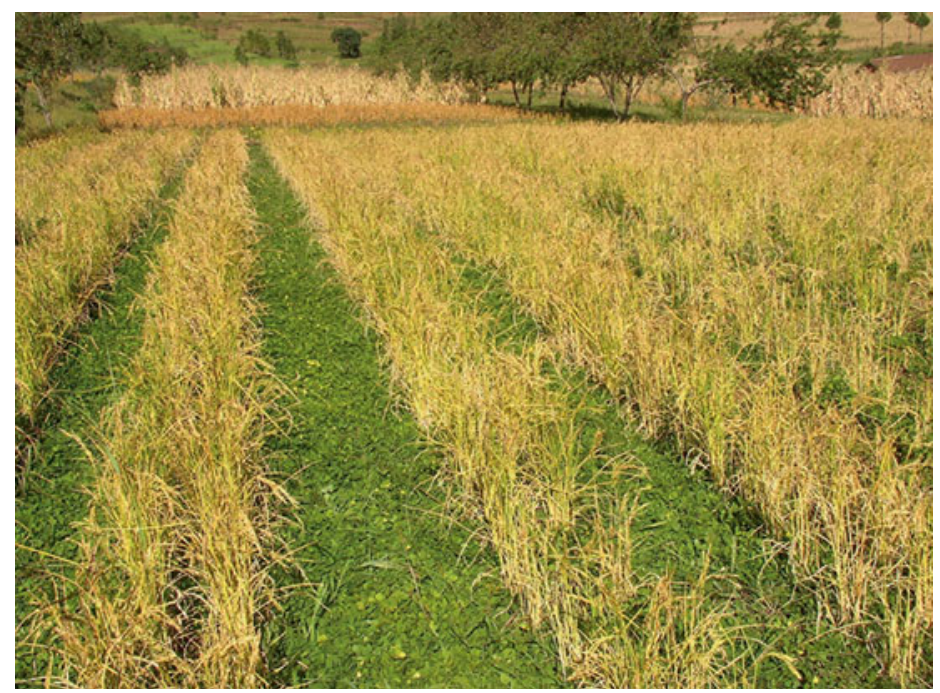

Fig. 1 Conservation agriculture: upland rice on a perennial groundnut live cover (Madagascar)

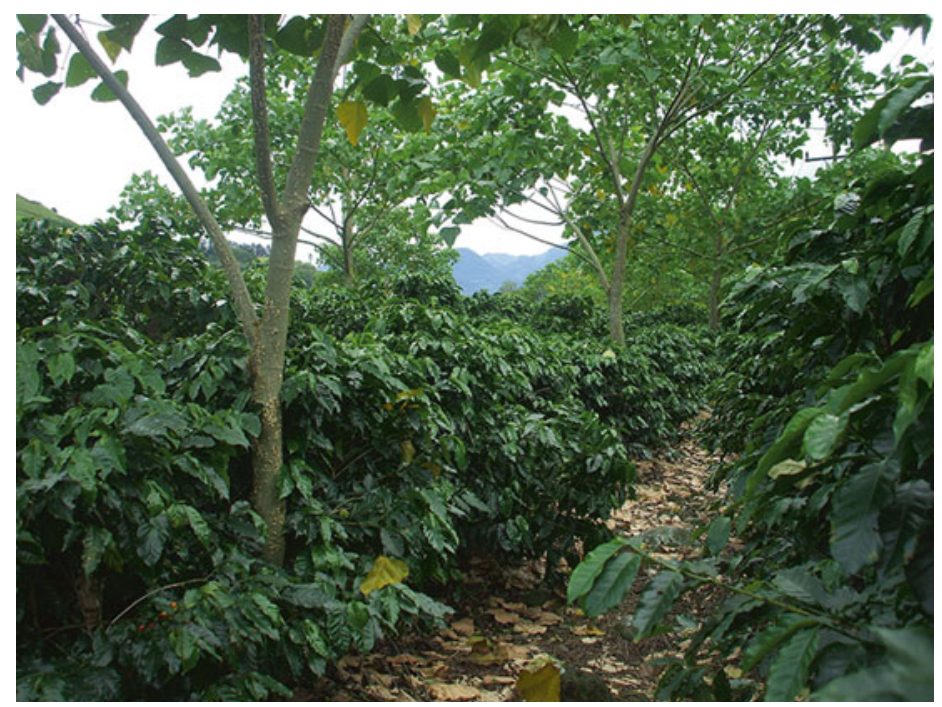

Fig. 2 Agroforestry: coffee under Erythrina shade trees (Costa Rica)

regulation ecosystem service. However, both approaches contribute to the major supporting ecosystem service of biodiversity conservation, and make producers and consumers benefit from indirect ecosystem services like increased human health due to reduced reliance on agrochemicals. 


\section{Lessons from Some Tropical Case Studies}

\section{Seed-Dressing with Targeted Systemic Insecticides}

The question of relevance of seed-dressing in ecological intensification is illustrated by the use of insecticides against black beetles in rainfed cereals, notably upland rice in Madagascar. Unless seeds are treated with a systemic insecticide, these pests (Heteronychus spp.) completely prevent the development of upland rice production and the adoption of Direct-seeding, Mulch-based Cropping (DMC) systems (Fig. 3), conservation agriculture systems that otherwise provide a number of significant ecosystem services such as soil conservation and carbon sequestration (Ratnadass et al. 2006).

Results suggest that in some DMC systems, seed dressing, which is mandatory to control damage but only during the initial years following a break with conventional management, namely foregoing ploughing, becomes no longer necessary after a few years of such DMC management (Ratnadass et al. 2008). Beyond inducing changes in the below-ground fauna composition (e.g. replacement of herbivore taxa, particularly rhizophagous white grubs, by detritivorous species, including white grubs like Hexodon unicolor (Fig. 4), and facilitating activity of predators like tiger beetles, e.g. Hipparidium equestre (Fig. 5)), some DMC systems induce changes of the status of other white grub according to the organic status of the soil (e.g. having grubs of some black beetle species turn from rhizophagous to detritivorous) (Ratnadass et al. 2013).

Seed-dressing has a starter effect on biomass production, triggering biological processes particularly below ground, that more than compensate the minor adverse impact of the small amount of pesticide used (Ratnadass et al. 2012b). However, ways

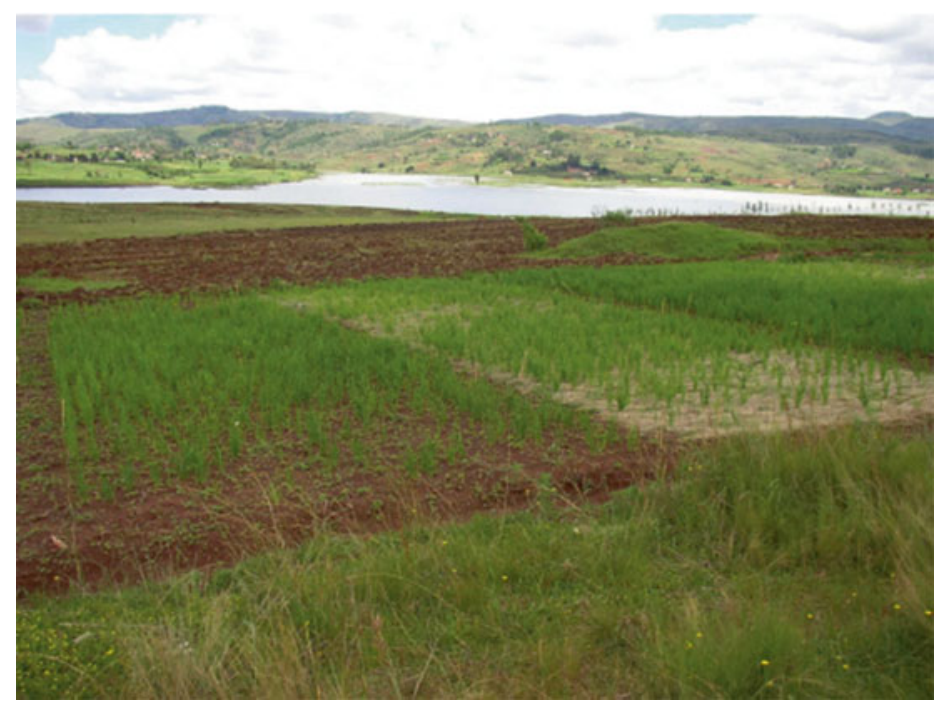

Fig. 3 Damage caused by black beetles (Heteronychus spp) to ploughed (left) and mulched (right) upland rice, with (background) and without (foreground) seed-dressing (Madagascar) 


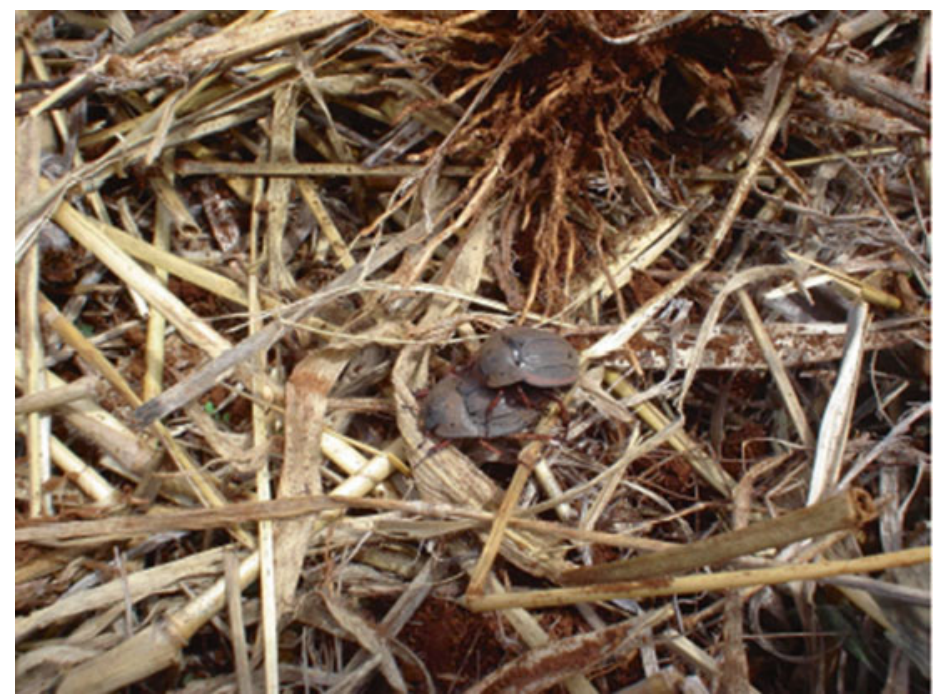

Fig. 4 Adults of a detritivorous white grub species, Hexodon unicolor, on a mulch

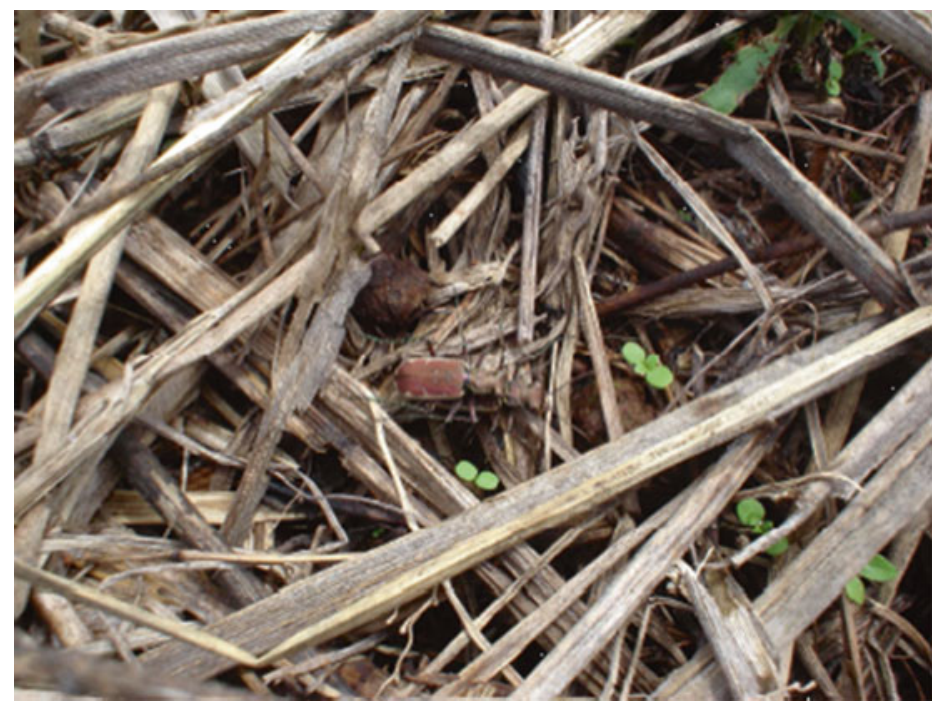

Fig. 5 Adults of a predatory tiger beetle (Hipparidium equestre), on a mulch (Madagascar)

of minimizing some non-negligible side-effects of neonicotinoid insecticides used in seed-dressing should be sought in the initial years when treatment is mandatory. Since rice, as a self-pollinated plant, does not require entomophilous pollination on the one hand, and that beekeeping may be of a particular importance in some regions like the south-eastern part of the island, a "push-pull" combination of bee-repelling (push) cover plants inside seed-dressed upland rice fields, with bee-attractive (pull) 


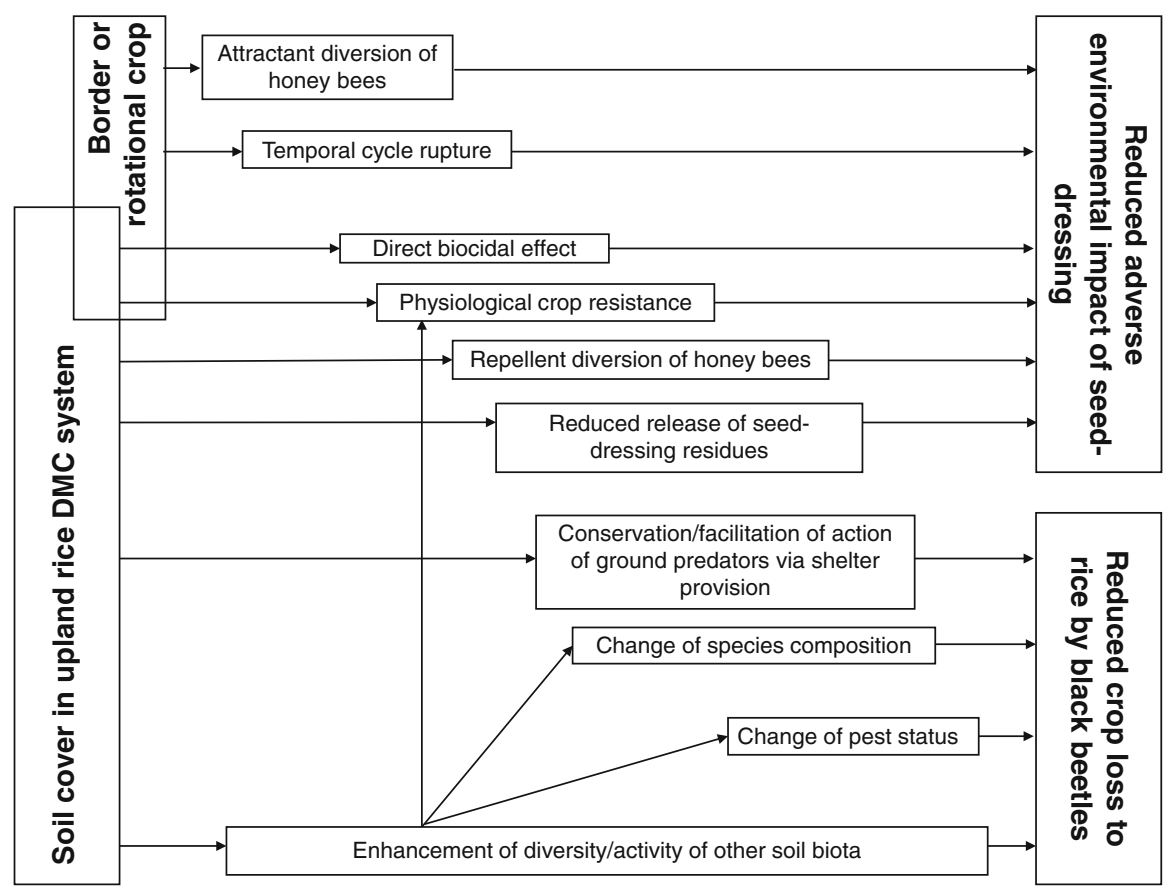

Fig. 6 Crop protection-related effects of an upland rice-based conservation agriculture system (After Ratnadass et al. 2008, 2012a, b, c, 2013). Ecosystem services beyond pest regulation, provided by this conservation agriculture system, are not shown

melliferous plants either as rice field borders, or as plots in rotation, would guarantee a harmonious rice cropping-beekeeping integration in these regions.

The way various ecological processes are harnessed to meet the objectives of reduced pest impact and minimal adverse environmental impact in an ecologically intensive crop protection system is presented in Fig. 6. It does not fit very well within the IPM framework since it involves systematic preventive chemical seeddressing. Nevertheless, studies are underway to replace synthetic seed-dressing insecticides by biological ones, either plant-derived or entomopathogenic (Ratnadass et al. 2012b, c; Razafindrakoto Raliearisoa et al. 2010).

So this case-study provides an example of a technique which is not IPM stricto sensu, but can still be part of the ecological intensification approach, as long as it boosts some ecological pest regulation processes, provides other ecological services, and is associated with measures that reduce other potential negative impacts.

\section{Use of GF-120 for Fruit Fly Control in Orchards}

GF-120, a mixture of food attractant and Spinosad, a biological insecticide at the rate of $0.02 \%$, was successfully used in an "attract \& kill" approach to control mango fruit flies in Benin (Vayssières et al. 2009). Since the mixture is "spot-sprayed" on 
Fig. 7 Maggot and damage of the jujube fruit fly Carpomya incompleta on a Sahel apple (Niger)

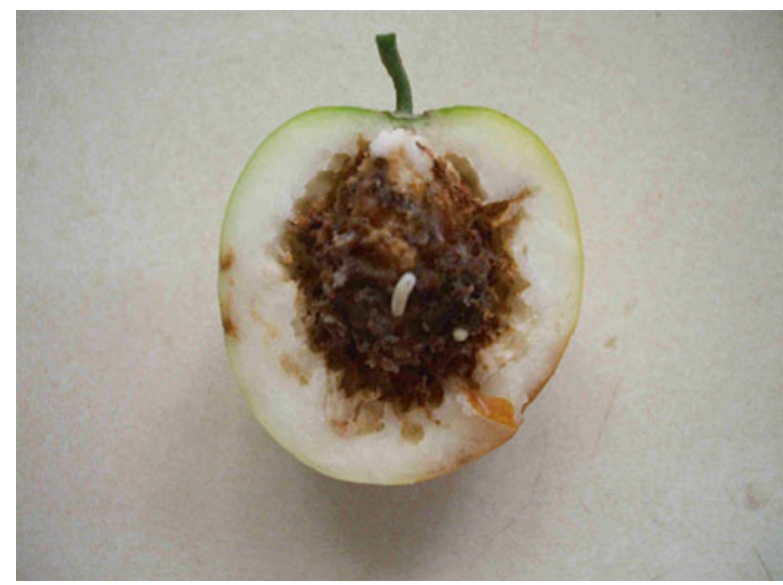

part of the canopy of the crop, it could be so only when the economic injury level is reached, and thus follow IPM principles. Furthermore, as part of IPM Principle 7, namely that of anti-resistance strategy, chemical insecticides other than Spinosad could be recommended in alternation.

There is actually a second case when GF-120 could be used both as a repellent to protect "Sahel apples" (fruits from grafted jujube trees) from the specialist fruit fly Carpomya incompleta (Fig. 7), and as an "attractant \& killer" to protect watermelon, which is part of the Dryland Eco-Farm system (Fatondji et al. 2011), along with jujube tree, from oliphagous Dacus fruit flies, thus "killing two flies with one spray", and even a third one, namely Bactrocera invadens, which is gaining importance as a highly polyphagous fruit pest in Niger (Zakari-Moussa et al. 2012). In this latter case (shown in Fig. 8), since the repellent effect may be considered a preventive measure, it fits well within ecological engineering in agroecology, or ecological intensification for crop protection approaches.

This example illustrates how a single treatment method can be either "curative" and therefore comply with IPM principles, or be systematic and therefore not theoretically compatible with IPM, while still complying with ecological intensification, although only "mimicking" natural processes.

\section{Increased Positive Effect of Weaver Ants on Fruit Trees}

The tree-inhabiting weaver ant Oecophylla (Oecophylla smaragdina in Asia and Oceania, and O. longinoda in Africa (Fig. 9)) effectively protects tropical tree crops as it actively patrols canopies and preys upon or deters a wide range of potential pests. Weaver ant husbandry in citrus orchards dates back to the fourth century AD in southern China and is recognized as the oldest known instance of man-mediated biological control (Huang and Pei 1987). In Vietnam, it is effective at reducing 


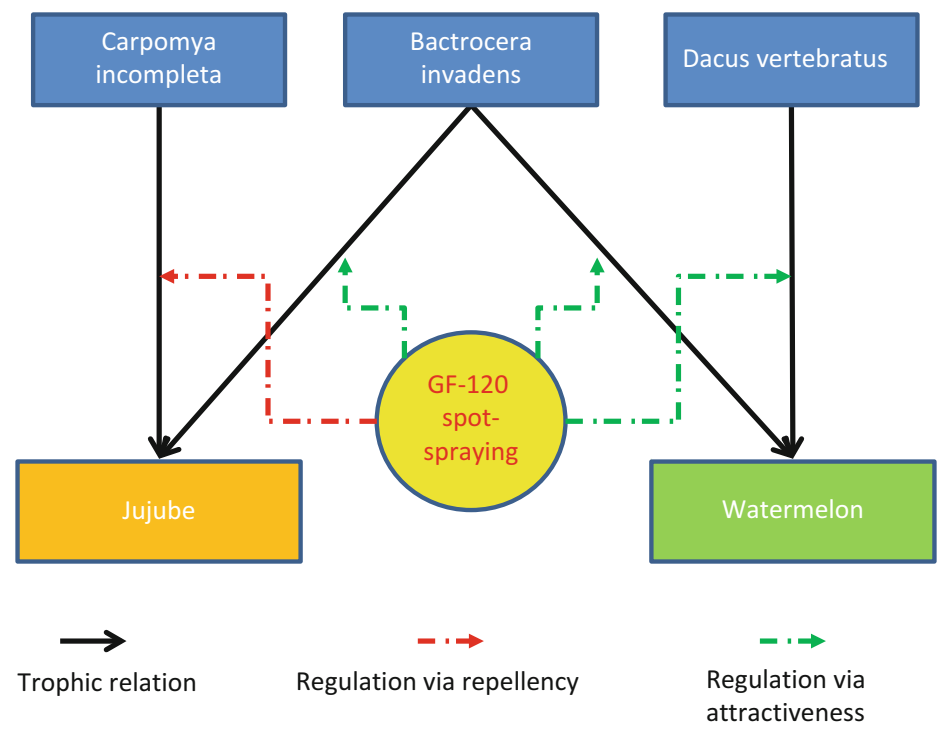

Fig. 8 Representation of a "win-win" strategy to "kill three fly species with one spray" in a Dryland Eco-Farm system (Excerpted from Zakari-Moussa et al. 2012)

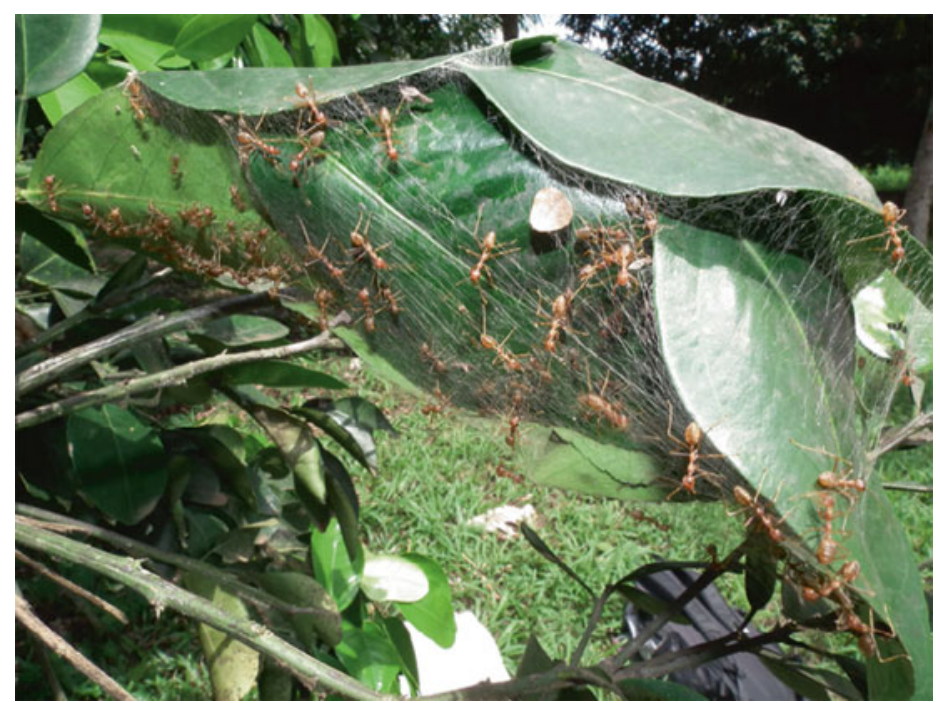

Fig. 9 Oecophylla longinoda ants weaving a nest on a citrus tree (Benin)

populations of a range of citrus pests (stinkbugs, swallowtail, aphids, leafminer, rindborer: Barzman 2000). Weaver ants are also used against coconut-sucking bugs in Africa and Oceania (Barzman 2000; Seguni et al. 2011), and mango fruit flies in Africa (Van Mele et al. 2007). 


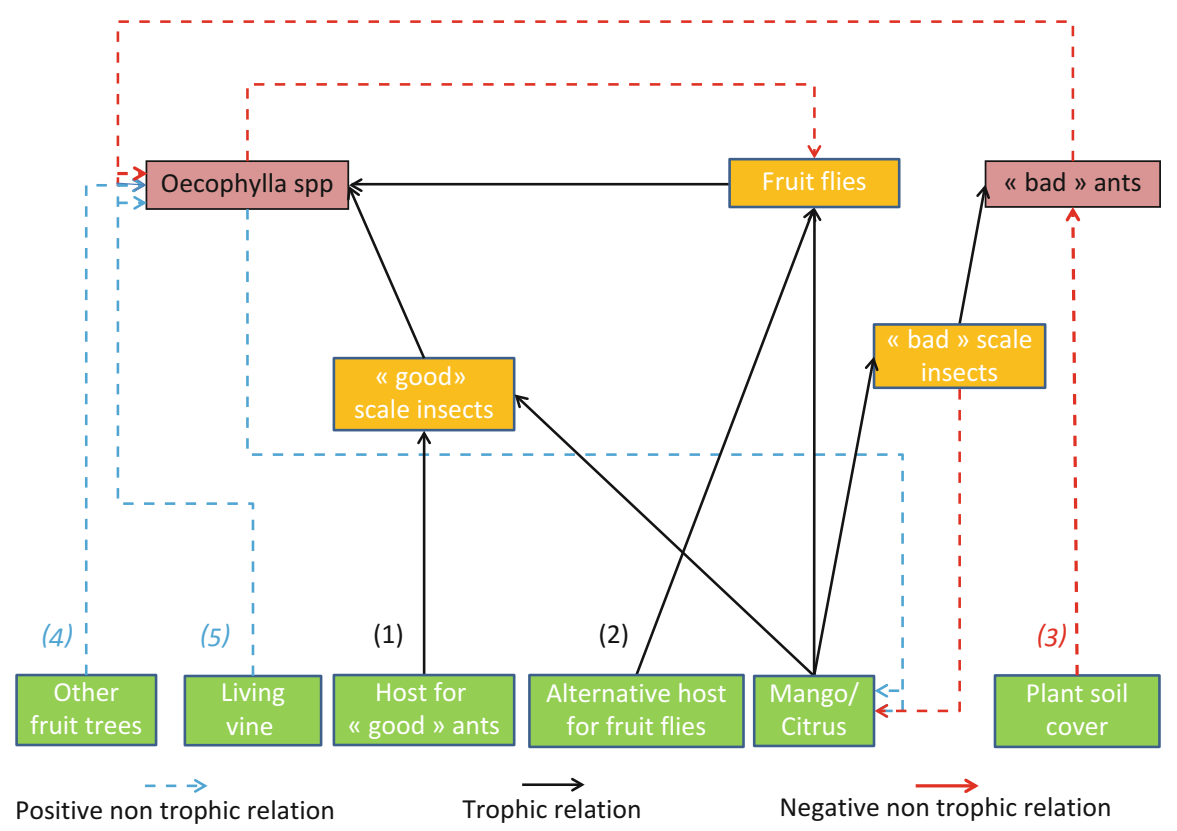

Fig. 10 Representation of an ecologically-engineered orchard/grove optimized vis-à-vis positive effect of weaver ants via food webs (After Barzman et al. 1996; Barzman 2000; Van Mele et al. 2007, 2009; Seguni et al. 2011). Provision of plants suitable for weaver ant nests via host suitability for ant-tended little-damaging, non viral disease-transmitting scale insects (1), or intercropping with fruit trees with leaves suitable for ant nests in the case of coconut groves (4); Suppression of alternate fruit fly hosts in orchards or in their vicinity (2); Maintenance of plant cover in orchards to prevent antagonistic ants to displace weaver ants from the fruit tree canopy and to bring with them damaging and viral disease-transmitting scale insects (3); Provision of living vines to facilitate patrolling of weaver ants on fruit trees and their positive effect either directly on citrus, or indirectly via pest predation and/or repellency on citrus and mango fruit flies and on other citrus and coconut pests (5)

Figure 10 shows how ecological processes in orchards and groves may be harnessed, particularly playing on plant diversity, so as to improve positive action of weaver ants on fruits, via various pathways.

The active human-mediated establishment of ants creates "ecologically-engineered" orchards that fit very well within ecologically intensive crop protection. Since no chemical pesticides are involved, this approach also provides an image of what an "ultimate IPM" agroecosystem could be.

\section{Conclusion}

With the new European legislative and R\&D efforts, IPM is receiving renewed attention and the concept of prevention - IPM principle 1 - via the design of cropping systems inherently less vulnerable to pests is given centre stage. The term 
"ultimate IPM" was introduced by Cliff Ohmart (personal communication, 2008) as an ideal and unattainable situation where the cropping system design has been so well crafted that no crop protection intervention is needed to manage pests once the system is in place. Originally thought of as an artefact useful to create the IPM continuum, which is itself a useful tool to include nearly all farmers onboard, the authors believe it is also a useful yardstick on the horizon to compare the goals of the various approaches. This might imply a change of perspective. In current IPM development, researchers and advisors start from a conventional agroecosystem and gradually remove inputs from it. The new approach would be to start from a nearly natural ecosystem to which inputs are gradually added when absolutely necessary (Brown 1999).

This new perspective would bring IPM closer to ecological intensification for crop protection (even closer then under the "integrated production" concept) and to low-input organic farming giving priority to agroecological practices such as polyculture, use of on-farm produced inputs and preventive strategies. It would also help to distinguish it from a low-level of IPM embodied by the pun "Intelligent Pesticide Management" (Nicholls and Altieri 2004), or from large-scale organic farming. The same criticism is actually applicable to large-scale organic farming regarding the practice of substitution - rather than redesign - translating to reliance on broadspectrum "natural" pesticides, either mineral, e.g. copper and sulphur in organic viticulture, or broad spectrum plant-derived insecticides e.g., until recently rotenone, and the repeated release of massive numbers of short-lived natural enemies in augmentative biological control as a substitute to chemical treatments. It also applies to industrial no-till systems that claim to be agroecological even though many are reliant on GM crops and herbicide applications.

Given scientific evidence and increasing societal pressure due to the perception that the main risks now come from humans rather than from "Nature" (Beck 1986), it is likely that the current trend in pesticide use reduction will speed up. In this context, one should be ready to face situations such as the ban of DDT in US agriculture in 1972, the phase-out of a set of "dirty dozen" pesticides on rice in Indonesia in the late 1970s, or the "special period" in Cuba following the dissolution of the Soviet Union in the early 1990s (Altieri et al. 2012; Funes-Monzote et al. 2009). Although those were drastic measures, they largely contributed to the rise of IPM in the USA and Indonesia, and of agroecology - especially in its crop protection dimension - in Cuba.

We depict in Figs. 11 and 12 the current and future positioning of the major pathways to sustainable agriculture discussed in this paper, as compared to conventional intensive agriculture.

"Ultimate IPM", as depicted in Fig. 12, will thus no longer rely on increased efficiency of synthetic pesticides, and much less on some substitution of inputs than organic farming, with an increased share of re-design of the cropping system (more than organic farming, although less than agroecology and ecological intensification). As compared to the other approaches, IPM will continue to be more "pest regulation service-oriented", while ecological intensification will be more "food provision service-oriented". 

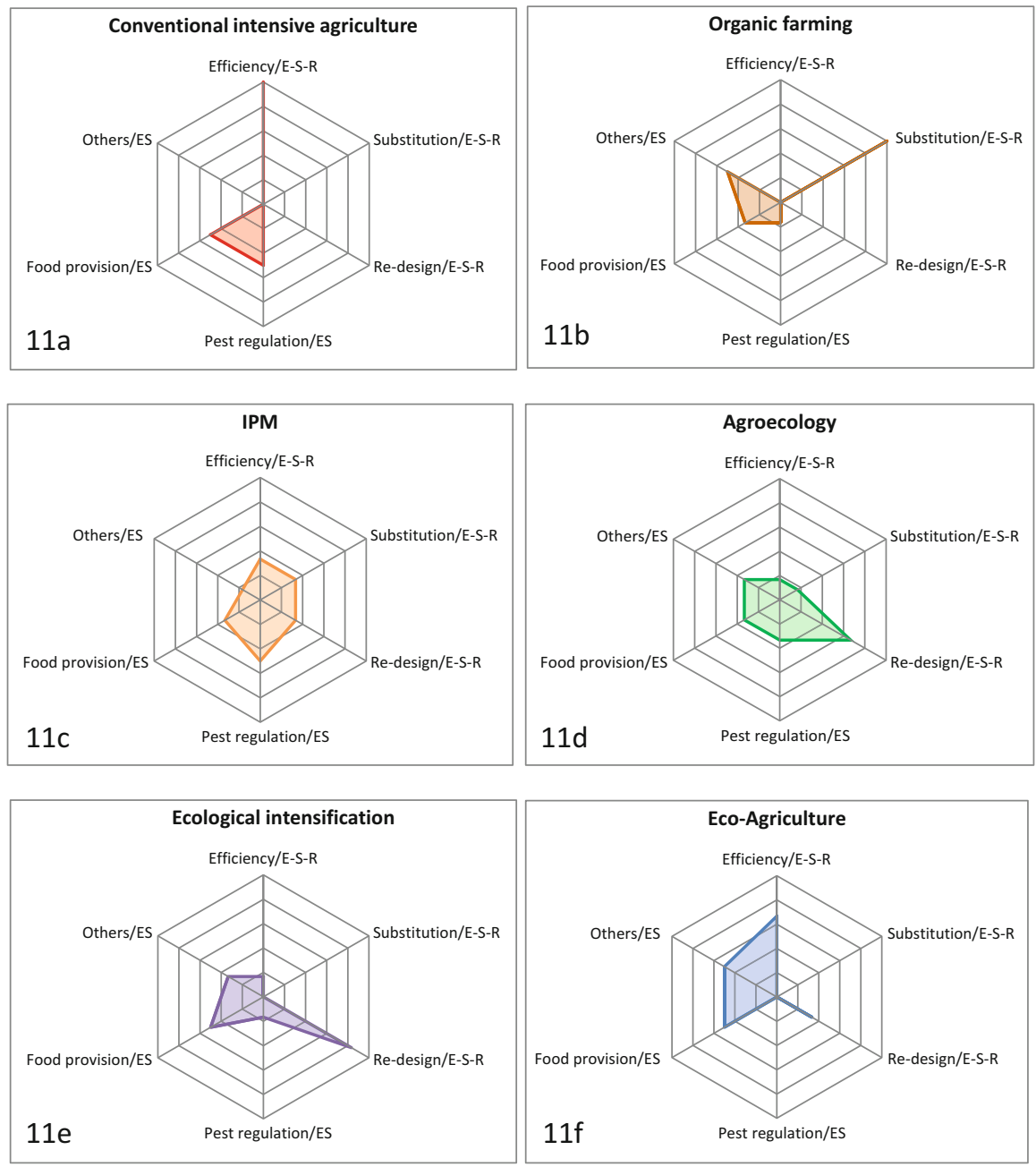

Fig. 11 Radar graphs showing the current positioning (on $0-100 \%$ scales) of five pathways to sustainable agriculture (11b thru 11f), as compared with conventional intensive agriculture (11a), according to their respective share between the three components of the Efficiency Substitution - Re-design (E-S-R) framework (top-right part of the graphs) and their respective contributions to three types of ecosystems services (ES): Pest regulation, Food provision, and other ES, including Human \& Environmental health and Biodiversity conservation (bottom-left part of the graphs)

We thus propose to consider IPM and crop protection in ecological intensification as complementary rather than conflicting approaches. Both approaches aim at managing rather than eradicating pests. Both allow pesticide use in certain circumstances. Future avenues to develop more sustainable crop protection could focus on 


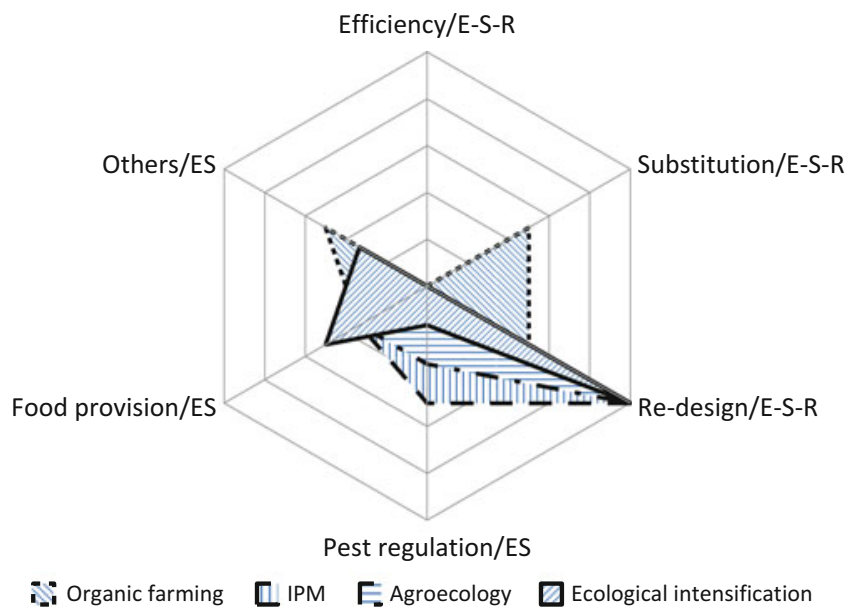

Fig. 12 Radar graph showing the positioning according to the same lines as in Fig. 11, of ecological intensification as compared to the evolution of three of the above pathways, namely IPM in its "ultimate" form, Organic farming restricted to its "low-input" form, and Agroecology excluding the industrial no-till systems

the management of biodiversity within a two-pronged approach, as suggested by Avelino et al. (2011):

- reduction of pesticide use in intensified systems, while retaining as high a yield as possible

- yield increase in rustic or low-technology systems, while maintaining ecological functions of pest and disease control at high levels.

The engineering stance of ecological intensification makes it suited to reconciling traditionally descriptive disciplines around ecology and anthropology of indigenous knowledge systems with more action-oriented fields such as agricultural sciences, entomology, plant pathology, or weed sciences. It can also enrich fields such as the French school of agronomy - a field that historically only considered physico-chemical processes, their interactions with crop physiology and agronomic practices - with aspects on biological interactions and regulation processes in agroecosystems (Hénin 1967; Wezel et al. 2009).

Finally, considering the current climate change and globalization contexts, one must admit that agriculture in the northern hemisphere may benefit from the experience of research in the tropics to anticipate increased pest and disease risks. On the one hand, in the tropics, biodiversity levels, including those of destructive organisms, are higher, and life cycles of pests and pathogens shorter than in temperate areas. On the other hand, high "resource" biodiversity levels in most tropical agroecosystems make it possible to design cropping systems that are more sustainably resilient to crop pests and diseases by relying on increased biodiversity/ecological 
regulation processes instead of non-renewable and toxic inputs. In this respect, we hope that the case studies provided here are food for thought for future development, particularly in the context of global climate change, globalization of exchanges, and increased societal pressure against pesticide use, in view of designing agroecosystems resilient vis-à-vis invasive and emerging pests.

Acknowledgments The authors wish to thank the Endure network since the idea of this chapter emerged from discussions held at Volterra, Italy, during the 2012 Endure Summer School.

\section{References}

Ahmed GJU, Hossain ST, Islam MR, Rabbi MF (2004) Rice-duck farming reduces weeding and insecticide requirement and increases grain yield and income of farmers. Int Rice Res Notes 29:73-76

Altieri MA (1995) Agroecology: the science of sustainable agriculture, 2nd edn. Westview Press, Boulder

Altieri MA (2004) Agroecology versus ecoagriculture: balancing food production and biodiversity conservation in the midst of social inequity. CEESP Occas Pap 3:8-28

Altieri MA, Nicholls CI (2012) Agroecology scaling up for food sovereignty and resiliency. In: Lichtfouse E (ed) Sustainable agriculture reviews 11. pp 1-29. Springer, Dordrecht

Altieri MA, Gurr GM, Wratten SD (2004) Genetic engineering and ecological engineering: a clash of paradigms or scope for synergy? In: Gurr GM, Wratten SD, Altieri MA et al (eds) Ecological engineering for pest management: advances in habitat manipulation for arthropods. CSIRO Publishing, Collingwood, pp 13-31

Altieri MA, Funes-Monzote FR, Petersen P (2012) Agroecologically efficient agricultural systems for smallholder farmers: contributions to food sovereignty. Agron Sustain Dev 32:1-13

Ammann K (2005) Effects of biotechnology on biodiversity: herbicide-tolerant and insect-resistant GM crops. Trends Biotechnol 23:388-394

Avelino J, Ten Hoopen GM, DeClerck F (2011) Ecological mechanisms for pest and disease control in coffee and cacao agroecosystems of the neotropics. In: Rapidel B, Le Coq JF, Beer J (eds) Ecosystem services from agriculture and agroforestry: measurement and payment. Earthscan Publications, London, pp 91-117

Barzman MS (2000) Weaver ants in orchards and groves. In: Stoll G (ed) Natural crop protection in the tropics. Margraf Verlag, Weikersheim, pp 99-100

Barzman MS, Mills NJ, Nguyen TTC (1996) Traditional knowledge and rationale for weaver ant husbandry in the Mekong delta of Vietnam. Agr Hum Val 13:2-9

Beck U (1986) Risikogesellschaft. Suhrkamp Verlag, Francfort

Bellon S, de Sainte Marie C, Lauri PE, Navarrete M, Nesme T, Plénet D, Pluvinage J, Habib R (2006) La production fruitière en France: le vert est-il dans le fruit? Le Courrier de l'environnement de l'INRA 53:5-18

Birch ANE, Begg GS, Squire GR (2011) How agro-ecological research helps to address food security issues under new IPM and pesticide reduction policies for global crop production systems. J Exp Bot 62:3251-3261

BLW (Bundesamt für Landwirtschaft) (2013) Agrarbericht 2012. Download BLW - Agrarbericht 2012. http://www.blw.admin.ch/dokumentation/00018/00498/01688/ind ex.html?lang = de

Boller EF, Avilla J, Joerg E, Malavolta C, Wijnands FG, Esbjerg P (2004) Integrated production, principles and technical guidelines. IOBC WPRS Bull 27:1-49

Bonny S (2011) L'agriculture écologiquement intensive: nature et défis. Cah Agric 20:451-462

Brown MW (1999) Applying principles of community ecology to pest management in orchards. Agric Ecosyst Environ 73:103-106 
Carson R (1962) Silent spring. The Riverside Press, Cambridge, MA

Chandler LD, Faust RM (1998) Overview of areawide management. J Agric Entomol 15:319-325

Cook SM, Khan ZR, Pickett JA (2007) The use of push-pull strategies in integrated pest management. Annu Rev Entomol 52:375-400

Darnhofer I, Lindenthal T, Bartel-Kratochvil R, Zollitsch W (2010) Conventionalisation of organic farming practices: from structural criteria towards an assessment based on organic principles. A review. Agron Sustain Dev 30:67-81

Deguine JP, Ferron P, Russell D (2008) Protection des cultures: de l'agrochimie à l'agroécologie. Quae, Versailles

Doré T, Makowski D, Malézieux E, Munier-Jolain N, Tchamitchian M, Tittonell P (2011) Facing up to the paradigm of ecological intensification in agronomy: revisiting methods, concepts and knowledge. Eur J Agron 34:197-210

ENDURE (2011) On the implementation of the eight principles of IPM. 15 pp. http://www.endurenetwork.eu/about_ipm/endure_position_papers

Fatondji D, Pasternak D, Nikiema A, Senbeto D, Woltering L, Ndjeunga J, Abdoussalam S (2011) The dryland eco-farm: a potential solution to the main constraints of rain-fed agriculture in the semi-arid tropics of Africa: exploring the scientific facts. In: Bationo A, Waswa B, Okeyo JM, Maina F, Kihara J (eds) Innovations as key to the green revolution in Africa. Springer, Dordrecht, pp 1115-1123

Funes-Monzote FR, Monzote M, Lantinga EA, Ter Braak CJF, Sánchez JE, Van Keulen H (2009) Agro-ecological indicators (AEIs) for dairy and mixed farming systems classification: identifying alternatives for the Cuban livestock sector. J Sustain Agric 33:435-460

Furuno T (2001) The power of duck: integrated rice and duck farming. Tagari Publications, Tasmania

Griffon M (2006) Nourrir la planète. Odile Jacob, Paris

Griffon M (2013) Qu'est-ce que l'agriculture ecologiquement intensive? Quae, Versailles

Gurr GM, Scarratt SL, Wratten SD, Berndt L, Irvin N (2004) Ecological engineering, habitat manipulation and pest management. In: Gurr GM, Wratten SD, Altieri MA (eds) Ecological engineering for pest management: advances in habitat manipulation for arthropods. CSIRO Publishing, Collingwood, pp 1-12

Guthman J (2000) Raising organic: an agro-ecological assessment of grower practices in California. Agric Hum Val 17:257-266

Hénin S (1967) Les acquisitions techniques en production végétale et leurs applications. Économie Rurale 74:31-44

Hill SB, MacRae RJ (1995) Conceptual frameworks for the transition from conventional to sustainable agriculture. J Sust Agric 7:81-87

Howard A (1943) An agricultural testament. Oxford University Press, London

Huang HT, Pei Y (1987) The ancient cultured citrus ant, a tropical ant is used to control insect pests in southern china. Bioscience 37:665-671

IPM CRSP/Virginia Tech (2011) http://www.oired.vt.edu/ipmcrsp/AboutUs/FAQs.html

Jackson W, Piper J (1989) The necessary marriage between ecology and agriculture. Ecology 70:1591-1593

Kennedy G (2008) Integration of insect-resistant genetically modified crops within IPM programs. In: Romeis J, Shelton AM, Kennedy G (eds) Integration of insect-resistant genetically modified crops within IPM programs (progress in biological control). Springer, New York, pp 1-26

Khan ZR, Midega CAO, Bruce TJA, Hooper AM, Pickett JA (2010) Exploiting phytochemicals for developing a 'push-pull' crop protection strategy for cereal farmers in Africa. J Exp Bot 61:4185-4196

Letourneau DK, van Bruggen AHG (2006) Crop protection in organic agriculture. In: Kristiansen P, Taji A, Reganold J (eds) Organic agriculture - a global perspective. CSIRO Publishing, Collingwood, pp 93-121

Maguire LA, Justus J (2008) Why intrinsic value is a poor basis for conservation decisions. Bioscience 58:910-911

Malézieux E (2012) Designing cropping systems from nature. Agron Sustain Dev 32:15-29 
Mathijs E (2012) Sustainable food consumption and production in a resource-constrained world. The futures of agriculture. Brief No. 01 - English. Global Forum on Agricultural Research (GFAR), Rome

McNeely J, Scherr S (2003) Ecoagriculture: strategies to feed the world and save wild biodiversity. Island Press, Washington, DC

Meissle M, Romeis J, Bigler F (2011) Bt maize and integrated pest management - a European perspective. Pest Manag Sci 67:1049-1058

Millennium Ecosystem Assessment (2005) Ecosystems and human well-being: synthesis. Island Press, Washington, DC

Mitsch WJ, Jorgensen SE (2003) Ecological engineering: a field whose time has come. Ecol Eng 20:363-377

Moore Lappé F, Collins J, Rosset P, Esparza L (1998) World hunger: twelve myths. Grove Press, New York

Nash R (1967) Wilderness and the American mind. Yale University Press, New Haven/London

Nicholls CI, Altieri MA (2004) Agroecological bases of ecological engineering for pest management. In: Gurr GM, Wratten SD, Altieri MA (eds) Ecological engineering for pest management: advances in habitat manipulation for arthropods. CSIRO Publishing, Collingwood, pp 33-54

Ohmart C (2008) IPM implementation at field level: "What are the impediments to grower adoption of IPM? Why do they exist and what can be done to get around them?". ENDURE International Conference 2008 Diversifying crop protection, 12-15 October 2008, La GrandeMotte, France, pp 1-10. http://www.endure-network.eu/international_conference_2008/ proceedings/monday_october_13

Ohmart C (2009) IPM implementation - overcoming barriers to grower adoption. Pestic News 85:22-25

Perfecto I, Vandermeer J (2008) Biodiversity conservation in tropical agroecosystems: a new conservation paradigm. Ann NY Acad Sci 1134:173-200

Perfecto I, Vandermeer J, Masa A, Soto Pinto L (2005) Biodiversity, yield, and shade coffee certification. Ecol Econ 54:435-446

Phalan B, Onial M, Balmford A, Green RE (2011) Reconciling food production and biodiversity conservation: land sharing and land sparing compared. Science 333:1289-1291

Power AG (2010) Ecosystem services and agriculture: tradeoffs and synergies. Philos Trans R Soc Lond B 365:2959-2971

Pretty J (2008) Agricultural sustainability: concepts, principles and evidence. Philos Trans R Soc Lond B 363:447-465

Rahbi P (2008) Manifeste pour la terre et l'humanisme: pour une insurrection des consciences. Actes Sud, Paris

Ratnadass A (2013) Room for plant derived pesticides in agroecological management of crop pests? Experience from some African cropping systems. In: Ogendo JO, Lukhoba CW, Bett PK, Machocho AK (eds) Proceedings of the first international conference on pesticidal plants, ADAPPT-Network. Egerton University, Nakuru, pp 179-183. Nakuru, Kenya

Ratnadass A, Wink M (2012) The phorbol ester fraction from Jatropha curcas seed oil: potential and limits for crop protection against insect pests. Int J Mol Sci 13:16157-16171

Ratnadass A, Michellon R, Randriamanantsoa R, Séguy L (2006) Effects of soil and plant management on crop pests and diseases. In: Uphoff NT, Ball AS, Fernandes ECM, Herren HR, Husson O, Laing MV, Palm C, Pretty J, Sanchez P, Sanginga N, Thies J (eds) Biological approaches to sustainable soil systems. CRC Press, Boca Raton, pp 589-602

Ratnadass A, Rafamatanantsoa E, Rajaonera TE, Ramahandry F, Ramarofidy M, Randriamanantsoa R, Séguy L (2008) Dispositifs pour l'évaluation des impacts des systèmes de culture sur les dégâts des insectes terricoles sur le riz pluvial à Madagascar. Terre malgache 26:153-155

Ratnadass A, Fernandes P, Avelino J, Habib R (2012a) Plant species diversity for sustainable management of crop pests and diseases in agroecosystems: a review. Agron Sustain Dev 32:273-303

Ratnadass A, Razafindrakoto Raeliarisoa C, Andriamizehy H, Ravaomanarivo LH, Rakotoarisoa HL, Ramahandry F, Ramarofidy M, Randriamanantsoa R, Dzido JL, Rafarasoa LS (2012b) Protection of upland rice at Lake Alaotra (Madagascar) from black beetle damage (Heteronychus plebejus) (Coleoptera: Dynastidae) by seed dressing. Afr Entomol 20:177-181 
Ratnadass A, Randriamanantsoa R, Douzet JM, Rakotoalibera H, Andriamasinoro V, Rafamatanantsoa E, Michellon R (2012c) Evaluation des risques liés au traitement de semences contre les attaques d'insectes terricoles sur riz pluvial à Madagascar et d'alternatives biologiques aux molécules de synthèse. 1st Conference on Organic Rice Farming and Production Systems, Montpellier, France, 27-30 Aug 2012

Ratnadass A, Randriamanantsoa R, Rajaonera TE, Rabearisoa M, Rafamatanantsoa E, Moussa N, Michellon R (2013) Interaction between cropping systems and white grub (Coleoptera: Scarabeoidea) status (pest or beneficial) on upland rice. Cah Agric 22:432-441. doi: 10.1684/ agr.2013.064

Razafindrakoto Raeliarisoa C, Rakotoarisoa HL, Razafindrakotomamonjy A, Ratnadass A, Vercambre B (2010) Lutte biologique intégrée contre des insectes terricoles, Heteronychus spp à Madagascar, par un champignon entomopathogène sur riz pluvial en semis direct sous couverture végétale. Etude et Gestion des Sols 17:159-168

Reyers B, Polasky S, Tallis H, Mooney HA, Larigauderie A (2012) Finding common ground for biodiversity and ecosystem services. Bioscience 62:503-507

Röling N, van de Fliert E (1994) Transforming extension for sustainable agriculture: the case of integrated pest management in rice in Indonesia. Agric Hum Value 3:96-108

Rosset PM, Altieri MA (1997) Agroecology versus input substitution: a fundamental contradiction in sustainable agriculture. Soc Nat Resour 10:283-295

Seguni ZSK, Way MJ, Van Mele P (2011) The effect of ground vegetation management on competition between the ants Oecophylla longinoda and Pheidole megacephala and implications for conservation biological control. Crop Prot 30:713-717

Séguy L, Husson O, Charpentier H, Bouzinac S, Michellon R, Chabanne A, Boulakia S, Tivet F, Naudin K, Enjalric F, Chabierski S, Rakotodralambo P, Ramaroson I, Rakotondramana (2012) Principles and functioning of ecosystems cultivated under Direct seeding Mulch-based Cropping systems (DMC). CIRAD-GSDM-TAFA, Antananarivo

Shelton AM, Hatch SL, Zhao JZ, Chena M, Earle ED, Cao J (2008) Suppression of diamondback moth using Bt-transgenic plants as a trap crop. Crop Prot 27:403-409

Stäubli A (1983) Le fruit d'une harmonie entre l'homme et la nature. Revue suisse de viticulture arboriculture horticulture 15:317-318

Steiner R (1924) Agriculture course, the birth of the biodynamic method, eight lectures and discussions. Skylark Books, Hastings

Stern VM, van den Bosch R, Hagen KS (1959) The integrated control concept. Hilgardia 29:81-101

Su P, Liao XI, Zhang Y, Huang H (2012) Influencing factors on rice sheath blight epidemics in integrated rice-duck system. J Integr Agric 11:1462-1473

Van Mele P, Vayssières JF, van Tellingen E, Vrolijks J (2007) Effects of an African weaver ant, Oecophylla longinoda, in controlling mango fruit flies (Diptera: Tephritidae) in Benin. J Econ Entomol 100:695-701

Van Mele P, Vayssières JF, Adandonon A, Sinzogan A (2009) Ant cues affect the oviposition behaviour of fruit flies (Diptera: Tephritidae) in Africa. Physiol Entomol 34:256-261

Vandermeer J (1995) The ecological basis of alternative agriculture. Annu Rev Ecol Syst 26:201-224

Vayssières JF, Sinzogan A, Ouagoussounon I, Korie S, Thomas-Odjo A (2009) Effectiveness of spinosad bait sprays (GF-120) in controlling mango-infesting fruit flies (Diptera Tephritidae) in Benin. J Econ Entomol 102:515-521

Wezel A, Bellon S, Doré T, Francis C, Vallod D, David C (2009) Agroecology as a science, a movement and a practice. A review. Agron Sustain Dev 29:503-515

Zakari-Moussa O, Ratnadass A, Vayssières JF, Nikiema A, Fatondji D, Salha H, Aboubacar K, Ryckewaert P, Pasternak D (2012) GF120 Effects on fruit fly species (Diptera: Tephritidae) in Sahelian agroforestry-based horticultural cropping systems. Fruits 67:333-339

Zehnder G, Gurr GM, Kuhne S, Wade MR, Wratten SD, Wyss E (2007) Arthropod pest management in organic crops. Annu Rev Entomol 52:57-80

Zhang W, Ricketts TH, Kremen C, Carney K, Swinton SM (2007) Ecosystem services and disservices to agriculture. Ecol Econ 64:253-26 